\title{
A MOVE ANALYSIS OF CONFERENCE ABSTRACTS IN APPLIED LINGUISTICS - PEDAGOGICAL IMPLICATIONS FOR TEACHING AND LEARNING ENGLISH FOR ACADEMIC PURPOSES
}

\author{
Cao Thi Hong Phuong* \\ English Faculty, Hanoi National University of Education, 136 Xuan Thuy, Cau Giay, Hanoi, Vietnam
}

Received 13 April 2018

Revised 27 July 2018; Accepted 30 July 2018

\begin{abstract}
This current paper presents the findings of move analysis of conference abstracts from the British Association for Applied Linguistics (BAAL). Reviewing different core perspectives of move analysis such as Biber et al. (2007); Swales (1981, 1990); Santos (1996), the paper employed suitable approaches namely Biber et al. (2007) for move identification and Santos (1996) for the analysis of moves in order to examine common linguistic features identified in the moves that are used to serve the social and communicative purpose of conference abstracts. The findings revealed that moves 1 (situating the research), 2 (presenting the research), and 3 (describing the methodology) are frequently included in the conference abstracts, whereas moves 4 (summarizing the results) and 5 (discussing the research) can be less frequent. It is concluded that this persuasive writing genre possesses 3 obligatory or strongly prototypical moves and 2 optional ones. Finally, some pedagogical implications are derived from the findings to inform further practice with regard to teaching and learning English for Academic Purposes (EAP) in second and foreign language learning contexts.
\end{abstract}

Keywords: move analysis, conference abstracts, applied linguistics, teaching and learning EAP

\section{Introduction}

Move analysis is used to explore rhetoric structures, language use and text organization of a particular genre. Biber et al. (2007) asserted that the goal of move analysis is to illustrate the communicative purposes of given texts by classifying the organizational patterns. This paper discusses a move analysis of eight conference abstracts in applied linguistics (AL) research which were selected from the BAAL 2017 booklet. The paper first identified and discusses some common language features identified in the moves, which are used to serve the communicative and social purpose of the

\footnotetext{
* Tel: 84-915020617
}

Email: hongphuongct@hnue.edu.vn conference abstracts. It is followed by some pedagogical implications for innovative EAP as well as the limitation of the analysis.

\section{Literature review}

Researchers in the field of applied linguistics have analyzed corpus-based moves from diverse perspectives. Schiffrin et al. (2001) argued that the analysis of moves could be grouped into three general categories namely (1) language use; (2) linguistic structure; and (3) social practices and ideological assumptions associating with language and/or communication. Amongst the three fundamental approaches to move analysis, the first two put the focus on the linguistic features of texts or discourse studies 
of linguistic organization beyond the sentence levels of particular texts. Research from this perspective has typically been conducted as qualitative inquiry research and is based on detailed analyses of a modest number of texts (Upton \& Cohen, 2009).

Move analysis was typically conducted as a top-down approach (where the focus is on ideas and meaning) to explore the discourse structure of texts from a genre; the text is portrayed as a sequence of 'moves', where each move displays a stretch of text serving a particular communicative (that is, semantic) purpose. The analysis frequently starts with the development of an analytical framework, identifying the move types occurring in this genre: these are the functional or communicative distinctions that move types can serve in the target genre. Biber et al. (2007: 23 ) also refer moves to "a section of texts that performs a specific communicative function," which can vary in length but contain at least one proposition. In other words, moves represent functional and semantic sets of texts which serve specific purposes.

With regards to abstracts, an underresearched, yet significant, realm of language studies associated with research process genres is the domain of abstracts. Following Swales (1990), some scholars have interested in this essential academic genre across a myriad of areas including applied linguistics (Santos 1996). However, among genre studies, conference abstracts have not received due attention; they, therefore, deserve scrutiny.

Research on move analysis focusing on conference abstracts has been attempted by genre scholars. Some interesting studies such as Berkenkotter \& Huckins (1995) found that successful conference abstracts (CA) included both predictable forms and contents. For example, Raisanen (2002) found 2 obligatory moves (statement of purpose and methods) as well as 3 optional moves (territory, results, and conclusion/implications) in conference abstracts (CA). Studies on move analysis have also yielded distribution of moves and their frequency in texts on a research article (RA). For instance, Swales' (1981, 1990) CARS (Create a Research Space) model on research article introduction shows a sequence of moves and steps (Biber et al., 2007). These authors have well acknowledged that an introduction of an RA most probably consists of 3 moves with several steps in each move which are: (1) establishing a territory, (2) establishing a niche, and (3) occupying a niche.

\section{Method}

Move analysis directly examines texts at the discourse level regarding their rhetorical goals and how they function to achieve those goals (Tardy, 2011). Specifically, the analysis of conference abstracts in AL helps investigate how academic writers offer a substantially condensed version (Santos, 1996) of their research. The steps of move identification in this paper are based on the top-down approach suggested in Biber et al. (2007). The insight into this approach can be presented as follows. First, the author determined the rhetorical purposes of the genre as well as the rhetorical function of each segment in its local context; the author then identified the possible moves of the genre. In the next step, the author conducted a pilot coding (Appendix B) to test and fine-tune definitions of move purposes. The author then coded the full set of texts and checked with the intercoder, who is an M.A graduate in applied linguistics, to ensure that move definitions 
are clear. The process of move analysis was discussed with the intercoder within two weeks. Eventually, two coders reached an agreement on the coding. The coding seems to "achieve high inter-rater reliability" (Biber et al., 2007: 35 ), as the two coders completely agreed on the common moves (Appendix A). The author finally identified the language features that are characteristic of the moves by the model of move analysis.

Several models of move analysis (e.g., Santos, 1996; Yakhontova, 2002; Halleck \&Connor, 2006; Upton \& Cohen, 2009) have been referred to; however, Santos' model (see Santos, 1996 for further details) was adopted for two main reasons. First, it provides a clearcut distinction between each move. Second, this framework has been directly employed to analyze abstracts in AL. Through the lens of move analytical framework of abstracts adapted from Santos (1996), this paper attempts to investigate the rhetorical moves of these eight abstracts and the linguistic realizations of moves. The framework of a five-move pattern was used to code the eight abstracts. Detailed illustrations are provided in Table 1 below.

Table 1. The framework for abstract analysis adapted from Santos (1996)

\begin{tabular}{|l|l|}
\hline \multicolumn{1}{|c|}{ Moves } & \multicolumn{1}{c|}{ Function/descriptions } \\
\hline Move 1: Situating the research (STR) & $\begin{array}{l}\text { Setting the background for the current research } \\
\text { topic generalization }\end{array}$ \\
\hline Move 2: Presenting the research (PTR) & $\begin{array}{l}\text { Stating the purpose of the study/research } \\
\text { questions and/or hypothesis }\end{array}$ \\
\hline Move 3: Describing the methodology (DTM) & $\begin{array}{l}\text { Describing the materials, subjects, variables, } \\
\text { procedures }\end{array}$ \\
\hline Move 4: Summarising the results (STR) & Reporting the main findings of the research \\
\hline Move 5: Discussing the research (DTR) & $\begin{array}{l}\text { Interpreting the results/findings and/or highlighting } \\
\text { the outcomes/giving recommendations/ } \\
\text { applications of the study/highlighting its outcomes }\end{array}$ \\
\hline
\end{tabular}

Mentioned earlier, the abstracts selected from BAAL 2017 booklet are considered by the conference organizing committee as highquality papers focusing on AL's engagement with policy and practice. The selection of abstracts to be analyzed was due to the nature of empirical-based studies. As these CA are independently structured texts, the purpose of which is to have an opportunity to present the study at a specific conference (Swales \& Feak, 2000) or to get funded from sponsors (Halleck \& Connor, 2006). In other words, $\mathrm{CA}$ is somewhat promotional. It means that these abstracts have already met the required success criteria of conference abstracts set by BAAL 2017 reviewers. The study aims to seek the answers to the research questions:

1) How frequently do the moves occur in the abstracts?

2) To what extent are the moves embedded?

3) How are linguistic features presented in each move?

\section{Results and discussion}

The paper first presents the findings regarding the rhetorical moves of these eight abstracts including the frequency of moves, 
the moves that are found embedded, it then discusses the linguistic realization of each move. Unlike Santos (1996) this paper does not discuss the sub moves. There are reasons as to why this study does not divide further into sub moves. The main reason is that the subdivision of sub moves in Santos's research of abstracts was mainly based on Swales's (1990) CARS model, which was not clearly distinguished (Swales, 2004; Pho, 2008).

\subsection{Move frequency}

The coding of moves allows different descriptive counts including move frequency as Biber et al. (2007) shows. In this case, the paper only discusses the overall frequency of instances of each type of move. Identifying move frequency can help determine which moves are obligatory or non-obligatory. As shown in Table 2 below, 3 moves namely STR, PTR, and DMC occur in all eight abstracts. This means that moves $1,2,3$ are obligatory. The results of move 2 and 3 confirmed the findings in Santos (1996) and Pho (2008), which found that 2 moves of PTR and DTM occur in almost all abstracts of their studies. Move 4 and 5 can be regarded as non-obligatory or optional, as they are found only in 3 and 5 out of the eight abstracts respectively.

Table 2. Move frequency

\begin{tabular}{|c|c|c|}
\hline Moves & Numbers of abstracts containing moves $\mathbf{( N = 8 )}$ & Percentages \\
\hline Move 1 & 8 & $100 \%$ \\
\hline Move 2 & 8 & $100 \%$ \\
\hline Move 3 & 8 & $100 \%$ \\
\hline Move 4 & 3 & $37.5 \%$ \\
\hline Move 5 & 5 & $62.5 \%$ \\
\hline
\end{tabular}

\subsection{Move embedding}

Halleck \& Connor (2006) argued that writers sometimes combine moves, so that one move can be embedded within another or two moves may occur in one sentence, which the authors called "blended" moves. The analysis from these eight abstracts shows that moves are embedded, and there are few instances, where DTM moves occur in the forms of phrases and clauses. For example:

1. (DTM) Drawing upon four-month fieldwork in three courts of a Chinese city that handles a large number of foreigner-related cases every year, (PTR) this paper explores the communication complexities in trial proceedings when foreign defendants, mostly from African countries, interact with Chinese interpreters in English.
2. (DTM) On the basis of discourse analysis of recordings of seven criminal hearings, (STP) this paper shows that communication becomes a challenge to both parties owing to their different 'varieties of English.'

3. (DTM) By examining a range of these publicly available texts related to A\&E services, (PTR) I explore the phenomenon of the model citizen construct, to discover and critique the discursive strategies present in these texts regarding 'correct' use of NHS services.

As observed, three embedded moves in the examples occur with DTM move (phrases), two of which are mixed with either PTR or STP moves. This finding shows a congruency with Pho (2008), which detected 
that the possibility of move embedded between DTM move and other moves is significant. Pho (2008) also mentioned that DTM move acts as a noun phrase in complex sentences. The explanation for the mixing of moves can also be found in studies by Santos (1996) and Pho (2008) because of the highly condensed nature of the abstract structure.

\subsection{Common linguistic features}

Writers' social and communicative purposes are closely related to the required linguistic characteristics, which are intentionally used to realize those purposes. Specifically, moves in abstracts of AL are also grounded in common communicative purposes and are realized in particular linguistic utterances (Swales, 1990). Some instances are mentioned in Santos (1996) regarding thematization, tense choices, and voice choices as well as in Halleck \& Connor (2006) regarding lexical devices. Similarly, Henry (2007) and Upton \& Cohen (2009) stated that linguistic features are found through lexico-grammatical analysis. In this section, the paper discusses the linguistic realization of each move in greater details.

\section{Move 1: Situating the research}

Move 1 offers the audience an orientation regarding background knowledge of the topic (Santos, 1996). It may be in the forms of stating current knowledge or citing previous research to lead to their studies. The analysis of grammatical features across eight abstracts reveals that the most typical tense used in move 1 is present perfect, with 13 instances and active voice is dominant, with ten instances. The table below describes all the verbs used in move 1 .
Table 3. The analysis of linguistic features in move 1

\begin{tabular}{|c|c|c|c|}
\hline Examples & $\begin{array}{c}\text { Active } \\
\text { voice }\end{array}$ & $\begin{array}{c}\text { Passive } \\
\text { voice }\end{array}$ & Abstract \\
\hline $\begin{array}{c}\text { has been reassured } \\
\text { has been established } \\
\text { has been on the rise }\end{array}$ & $\mathrm{V}$ & $\mathrm{V}$ & 1 \\
\hline $\begin{array}{c}\text { has attracted } \\
\text { rely on } \\
\text { is }\end{array}$ & $\mathrm{V}$ & $\mathrm{V}$ & 2 \\
\hline $\begin{array}{c}\text { have become } \\
\text { has identified } \\
\text { has not been studied }\end{array}$ & $\mathrm{V}$ & & 3 \\
\hline are (2) & $\mathrm{V}(2)$ & & 4 \\
\hline $\begin{array}{c}\text { has received } \\
\text { has been }\end{array}$ & $\begin{array}{c}\mathrm{V} \\
\mathrm{V}\end{array}$ & & 5 \\
\hline $\begin{array}{c}\text { have become } \\
\text { have taken } \\
\text { has received }\end{array}$ & $\begin{array}{c}\mathrm{V} \\
\mathrm{V}\end{array}$ & & 6 \\
\hline have recently been & $\mathrm{V}$ & & 7 \\
\hline $\begin{array}{c}\text { was } \\
\text { arose } \\
\text { were }\end{array}$ & $\begin{array}{c}\mathrm{V} \\
\mathrm{V}\end{array}$ & & 8 \\
\hline
\end{tabular}

As seen from Table 3, verb tenses across move 1 found few occurrences of the present simple tense and simple past tense. The figures for the present perfect tense with active voice are highly significant. The reason for this occurrence, according to Santos (1996), may be interpreted regarding generality. In other words, move 1 acts as a discoursal move, which claims a current state of knowledge generalizations. Reflecting moves in Halleck \& Connor (2006), it belongs to "TERRITORY" move, which also serves to introduce a general topic of research or to establish the physical location of the proposal.

\section{Move 2: Presenting the research}

The primary aim of this move is the reference to the author's own research by presenting the key features of the research 
questions or stating the purpose of the current study. Thus, move 2 is obviously signaled by a "grammatical subject that refers to the study itself" (Pho, 2008: 240). The following examples are given from abstract 1 to abstract 8 .

1. This project investigates

2. This paper explores

3. This study analyzed

4. This paper focuses

5. My paper draws

6. The study addresses

7. I explore

8. This ongoing postgraduate research aims

A predominating subject is a third person, singular such as "the paper" "this study" and "this project," which according to Santos (1996), refers to descriptive or purposive form. The clear preference for "this" can be explained the reasons for the writer effort to link the abstract to the central part of the paper and signal a report of what study is about. This is also in line with Khedri et al. (2013), which found one dominant feature referring to these narrowing and repetition of endophoric expressions. Most of the abstracts (seven out of eight) take present tense verbs with active voice, which intentionally refers to the description of the current research's purpose as opposed to previous ones.

\section{Move 3: Describing the methodology}

As analyzed from move 3 linguistic features in all eight abstracts are variably used. "V-ing" is used in abstracts 2, present simple tense is used in abstracts 1, 4, 5, 6 and past tense is found in abstract 3, 4. The most significant feature found from this move is the use of lexical items such as "data," "method," "methodologically," and "analysis," which refers directly to a means of conducting research (Upton \& Cohen, 2009). Mentioned earlier, move 3 is often embedded with other moves, as it occurs within the same sentence, acting as a clause in complex sentences, which can be categorized as hybrid moves (Santos, 1996).

\section{Move 4: Summarizing the results}

This move serves to provide answers to the research questions, it, therefore, tends to briefly summarize the significant findings of the studies (Santos, 1996) or discuss the anticipated results (Upton \& Cohen, 2009). The analysis of this move reveals that the most obvious lexical item is "the paper shows that"; "the research shows that" found in abstracts 2 and 6 . In other words, move 4 exponents do not refer to the author of the abstract, but to the research itself. Regarding the thematization, a neutral, impersonal, scientific tone (Santos, 1996) is portrayed in move 4.

\section{Move 5: Discussing the research}

DTR refers to the discussion of the findings, suggestions, recommendations or evaluation of the findings. The realization of linguistic features from this move shows that there are signals with the use of verbs such as "suggest" and "raise" with a preference of present simple tense as strategies to discuss the meanings of the key findings. Another linguistic characteristic found in move 5 is the use of modal verbs such as "could" in abstract 3 , which may act as a hedging device to tone down "claims to avoid potential audience rejection"(Hyland, 2004: 65).

Overall, the goal of the conference abstracts is to promote their work to other members of the field and the writers have to achieve this goal to sell the research (Yakhontova, 2002). The moves, which were analyzed to identify the rhetorical organization and linguistic features, in this case, may contribute to success criteria of accepted 
abstracts of the BAAL 2017 conference. As seen, moves 1, 2 and 3 are frequently included in these conference abstracts, whereas moves 4 and 5 can be less frequent. In other words, this persuasive writing genre may possess three obligatory or strongly prototypical moves and two optional ones. It can infer that presenters of BAAL 2017 conference are less likely to present research results in abstracts.

To sum up, the overall findings reveal that the genre of abstracts in AL has its typical structures which can be made up of five moves, each of which fulfills a particular purpose and is realized by specific linguistic features.

\section{Pedagogical implications and limitations}

Move analysis of conference abstracts has important implications for English language community users and learners from diverse backgrounds (Samar et al., 2014). The knowledge of move analysis plays a significant role in helping language learners, teachers and EFL writers understand the nature of written discourse and the ways discourse analysis contributes to our understanding of written language in use. By analyzing move analysis, we can gain better insight into the conventions of written language and what the writers mean. The analysis of moves, therefore, informs L2 learners, language teachers and EFL writers of explicit knowledge of how certain writing conventions are linguistically organized. Thus, pedagogic applications can be implemented in EFL contexts, which will be discussed in this section.

First, rhetorical structures of specific genres should be explicitly provided to novice EFL writers, graduate students who struggle with writing well-structured abstracts so that they can get accepted and certified (Hyland, 2004) in conferences in the field. For example, some linguistic features of conference abstracts can be incorporated into academic writing course for postgraduates so that they can be better prepared for their future world of publication. When students have the opportunities to gain core knowledge of move analysis, especially in CA and RA, they are informed of rhetorical structures of certain abstracts. Thus novice academics can be more reflective in shaping their future CA or RA of their research.

Second, a specific type of genre analysis can be adopted as a lexico-grammatical teaching approach in the settings (Henry, 2007; Flowerdew, 2016), where academic writing instruction is required such as composition and email writing. In the Vietnamese context, where a large number of language learners need to sit in VSTEP and IELTS writing exams, move analysis is extremely useful for them. Through scaffolding tasks of analyzing moves of academic essays, for example, L2 learners can examine language structures and linguistic features in relation to the required writing tasks. Thus, they can be better aware of useful lexico-grammatical patterns, which they may later transfer to their own writing work.

Last but not least, genre analysis allows language practitioners to adopt the language items in a more refined way for specific purposes of teaching, learning and linguistic research (Moreno \& Swales, 2018). Teachers can incorporate research findings of genre analysis in their teaching materials for EAP to optimize the effectiveness of EAP classrooms. For instance, teachers may consider genre-based syllabus, genre-based tasks and activities suggested in Henry and Roseberry (1998), Jalilifar (2009), Swales and Feak (2009), and Yayli (2011) for teaching academic writing to raise students' awareness of the specific genre' rhetorical organization 
and the linguistic realizations. Through such learning opportunities, learners can make use of these features to achieve coherent, purposeful written tasks.

Although the findings reveal that specific linguistic features are portrayed in 5 moves, they cannot be generalized to other cases. The reason for the limitation is the modest data, which somehow cannot represent the whole picture of analysis of conference abstracts in other disciplines.

\section{Conclusion}

As abstracts function "as advance indicators of the structure and content" of the complete research (Swales, 1990: 179), they are linguistically driven, which has been revealed through the move analysis. The results reveal that certain linguistic features in each move can be used as evidence to distinguish the moves and to justify the reasons why abstracts can be structured the way they are. The results show that these eight conference abstracts were written focusing on STR, PTR, and DTM rather than STP and DTR. Although the findings cannot be generalized beyond the context of this paper, they have, to some extent, shown the congruency with linguistic and rhetorical representation found in moves of RA and CA in $\mathrm{AL}$ from the literature. To conclude, the author would refer to Berkenkotter \& Huckin (1993) saying that conference abstracts as a genre, when closely investigated from specific perspectives, "reveal much about a discourse community's norms, epistemology, ideology and social ontology" (Berkenkotter \& Huckin, 1993: 501). Examining genres, therefore, substantially allows practitioners to get informed of genre knowledge for their professional development and to create appropriate teaching materials for classroom use.

\section{References}

Berkenkotter, C., \& Huckin, T. N. (1993). Rethinking Genre from a Sociocognitive Perspective. Written Communication, 10(4), 475-509. https://doi. org/10.1177/0741088393010004001

Biber, D., Connor, U., \& Upton, T. A. (2007). Discourse on the move: using corpus analysis to describe discourse structure. Philadelphia: John Benjamins Pub.

Flowerdew, L. (2016). A genre-inspired and lexicogrammatical approach for helping postgraduate students craft research grant proposals. English for Specific Purposes, 42, 1-12. https://doi. org/10.1016/j.esp.2015.10.001

Halleck, G. B., \& Connor, U. M. (2006). Rhetorical moves in TESOL conference proposals. Journal of English for Academic Purposes, 5(1), 70-86. https://doi.org/10.1016/j.jeap.2005.08.001

Henry, A. (2007). Evaluating language learners' response to web-based, data-driven, genre teaching materials. English for Specific Purposes, 26(4), 462-484. https://doi.org/10.1016/j. esp.2007.01.003

Henry, A., \& Roseberry, R. L. (1998). Raising Awareness of the Generic Structure and Linguistic Features of Essay Introductions. Language Awareness, 8(3-4), 190-200. https://doi. org/10.1080/09658419908667128

Hyland, K. (2004). Disciplinary discourses: social interactions in academic writing (Michigan classics ed). Ann Arbor: UMP.

Jalilifar, A. R. (2009). Research article in Applied Linguistics: A gender-based writing guide. Ahvaz: Shahid Chamran University.

Khedri, M., Heng, C. S., \& Ebrahimi, S. F. (2013). An exploration of interactive metadiscourse markers in academic research article abstracts in two disciplines. Discourse Studies, 15(3), 319-331. https://doi.org/10.1177/1461445613480588 
Moreno, A. I., \& Swales, J. M. (2018). Strengthening move analysis methodology towards bridging the function-form gap. English for Specific Purposes, 50, 40-63. https://doi.org/10.1016/j. esp.2017.11.006

Phuong Dzung Pho. (2008). Research article abstracts in applied linguistics and educational technology: a study of linguistic realizations of rhetorical structure and authorial stance. Discourse Studies, 10(2), 231-250. https://doi. org/10.1177/1461445607087010

Santos, M. B. (1996). The textual organization of research paper abstracts in applied linguistics. Text - Interdisciplinary Journal for the Study of Discourse,16(4). https://doi.org/10.1515/ text.1.1996.16.4.481

Schiffrin, D., Tannen, D. \& Hamilton, H. (eds) (2001). The Handbook of Discourse Analysis. Oxford: Blackwell.

Swales, J. (1981). Aspects of article introductions. Birmingham, UK: The University of Aston, Language Studies Unit

Swales, J. M. (1990). Genre analysis: English in academic and research settings. Cambridge: CUP.

Swales, J. (2004). Research genres: Explorations and applications. Ernst Klett Sprachen Publishing House.

Swales, J. M., \& Feak, C. B. (2000). English in today's research world: A writing guide. University of
Michigan, Ann Arbor, MI (EUA).

Swales, J., \& Feak, C. (2009). Abstracts and the writing of abstracts / John M. Swales, Christine B. Feak. (Michigan series in English for academic \& professional purposes). Ann Arbor: University of Michigan Press.

Samar, R. G., Talebzadeh, H., Kiany, G. R., \& Akbari, R. (2014). Moves and steps to sell a paper: A cross-cultural genre analysis of applied linguistics conference abstracts. Text \& Talk, 34(6), 759-785.

Raisanen, C. (2002). The conference forum: A system of interrelated genres and discursive practices. The language of conferencing, 69-93.

Tardy, C. (2011). Genre analysis. In K. Hyland \& B. Paltridge (Eds.), The Bloomsbury companion to discourse analysis (pp. 1-15). London: Bloomsbury.

Upton, T. A., \& Cohen, M. A. (2009). An approach to corpus-based discourse analysis: The move analysis as for example. Discourse Studies, 11(5), 585605. https://doi.org/10.1177/1461445609341006

Yakhontova, T. (2002). Selling' or 'telling'? The issue of cultural variation in research genres. Academic discourse, 10(1), 216-232.

Yayli, D. (2011). From genre awareness to cross-genre awareness: A study in an EFL context. Journal of English for Academic Purposes, 10(3), 121-129. 


\section{PHÂN TÍCH HÀNH ĐÔNG TU TÙ๋ TRONG TÓM TĂT BÁO CÁO HỘI THẢO NंGÀnH NGÔN NGŨ் HOC Ú̉NG DỤNG - HẢM Ý CHO HOẠT ĐỘNG DẠY VÄ HỌ̆C TIỂNG ANH KHOÄ HỌC}

\section{Cao Thị Hồng Phương}

Khoa Tiếng Anh, Truờng Đại học Su phạm Hà Nội, 136 Xuân Thủy, Cầu Giấy, Hà Nội, Việt Nam

Tóm tắt: Bài báo trình bày kết quả của nghiên cứu phân tích hành động tu từ của các bản tóm tắt báo cáo hội thảo trong lĩnh vực ngôn ngữ học ứng dụng. Xem xét các mô hình khác nhau về phân tích hành động tu từ của các tác giả như Biber et al., (2007); Swales (1981, 1990); Santos (1996), nghiên cứu này áp dụng mô hình phù hợp nhất, cụ thể là phương pháp tiếp cận của Biber et al., (2007) nhằm xác định hành động tu từ và của Santos (1996) nhằm phân tích các hành động tu từ, để xác định các tính năng ngôn ngữ trong các hoạt động được các tác giả áp dụng cho mục đích xã hội và giao tiếp trong các tóm lược hội thảo. Kết quả cho thấy hành động 1 (đánh giá bối cảnh nghiên cứu), 2 (trình bày nghiên cứu) và 3 (mô tả phương pháp luận) thường được đưa vào tóm lược hội thảo, trong khi hành động 4 (tóm tắt kết quả nghiên cứu) và 5 (thảo luận nghiên cứu) xuất hiện ít hơn. Có thể kết luận rằng thể loại ngôn bản này có 3 hành động mang tính bắt buộc hoặc khuôn mẫu và 2 hành động tùy chọn khác. Cuối cùng, tác giả trình bày một số đề xuất nhằm nâng cao chất lượng dạy và học viết tiếng Anh khoa học trong ngữ cảnh học ngôn ngữ thứ hai và ngoại ngữ.

Tù khóa: phân tích hành động tu từ, tóm tắt báo cáo hội thảo, ngôn ngữ học ứng dụng, dạy và học tiếng Anh khoa học

\section{APPENDIX A: MOVE IDENTIFICATION}

\begin{tabular}{|l|l|l|l|l|l|l|l|l|l|l|}
\hline \multicolumn{1}{|c|}{ Moves } & $\mathbf{1}$ & $\mathbf{2}$ & $\mathbf{3}$ & $\mathbf{4}$ & $\mathbf{5}$ & $\mathbf{6}$ & $\mathbf{7}$ & $\mathbf{8}$ & Frequency & $\begin{array}{c}\text { Inter-coder } \\
\text { agreement }\end{array}$ \\
\hline $\begin{array}{l}\text { Move 1: Situating the } \\
\text { research (Introduction) }\end{array}$ & $\mathrm{V}$ & $\mathrm{V}$ & $\mathrm{V}$ & $\mathrm{V}$ & $\mathrm{V}$ & $\mathrm{V}$ & $\mathrm{V}$ & $\mathrm{V}$ & 8 Obligatory & $100 \%$ \\
\hline $\begin{array}{l}\text { Move 2: Presenting the } \\
\text { research (Purpose) }\end{array}$ & $\mathrm{V}$ & $\mathrm{V}$ & $\mathrm{V}$ & $\mathrm{V}$ & $\mathrm{V}$ & $\mathrm{V}$ & $\mathrm{V}$ & $\mathrm{V}$ & 8 Obligatory & $100 \%$ \\
\hline $\begin{array}{l}\text { Move 3: Describing the } \\
\text { methodology (Methods) }\end{array}$ & $\mathrm{V}$ & $\mathrm{V}$ & $\mathrm{V}$ & $\mathrm{V}$ & $\mathrm{V}$ & $\mathrm{V}$ & $\mathrm{V}$ & $\mathrm{V}$ & 8 Obligatory & $100 \%$ \\
\hline $\begin{array}{l}\text { Move 4: Summarising the } \\
\text { results (Results) }\end{array}$ & $\mathrm{X}$ & $\mathrm{V}$ & $\mathrm{V}$ & $\mathrm{X}$ & $\mathrm{X}$ & $\mathrm{V}$ & $\mathrm{X}$ & $\mathrm{X}$ & 3 Optional & $100 \%$ \\
\hline $\begin{array}{l}\text { Move 5: Discussing the } \\
\text { research } \\
\text { Conclusion/discussion) }\end{array}$ & $\mathrm{V}$ & $\mathrm{V}$ & $\mathrm{V}$ & $\mathrm{V}$ & $\mathrm{X}$ & $\mathrm{V}$ & $\mathrm{X}$ & $\mathrm{X}$ & 5 Optional & $100 \%$ \\
\hline
\end{tabular}




\section{APPENDIX B: PILOT CODING}

\begin{tabular}{|c|}
\hline ABSTRACT 1 \\
\hline $\begin{array}{l}\text { Move 1: Situating the research (Introduction) } \\
\text { Since the 1980s, due to the political liberalization and the rise of the Taiwanization Movement, } \\
\text { multiculturalism has been reassured, and the importance of aboriginal language and culture rehabilitation } \\
\text { emphasized. After the } 1990 \mathrm{~s} \text {, several museums have been established as one of the political devices used } \\
\text { to help celebrate indigenous history and culture. At the same time, indigenous (cultural) tourism has been } \\
\text { on the rise and become an important of part of the cultural/ tourism industry. }\end{array}$ \\
\hline $\begin{array}{l}\text { Move 2: Presenting the research (Purpose) } \\
\text { This project investigates the exhibition texts in four Taiwanese museums in which aboriginal artefacts } \\
\text { are displayed. These include Shung Ye Museum of Formosan Aborigines, the National Prehistory } \\
\text { Museum, the Shihsanhang Museum of Archaeology and National Museum of Natural Science. By closely } \\
\text { examining museum texts, this study aims to understand the implicit dimension of how the properties } \\
\text { of the indexicality of language scripts and related semiotics are presented to construct ideologies and } \\
\text { sociocultural identity that shape and are shaped by the wider context of social structures. }\end{array}$ \\
\hline $\begin{array}{l}\text { Move 3: Describing the methodology (Methods) } \\
\text { The data are hybridised with different written texts and include a corpus of exhibition texts (labels) } \\
\text { displayed in public spaces, including flyers, brochures, posters, and signposts. This study adopts } \\
\text { multimodal discourse analysis as its methodological analysis tool because it involves both the analysis of } \\
\text { language use and different types of semiotic resource in such communications. }\end{array}$ \\
\hline $\begin{array}{l}\text { Move 4: Summarising the paper (Results) } \\
\text { None }\end{array}$ \\
\hline $\begin{array}{l}\text { Move 5: Discussing the research (Conclusion/discussion) } \\
\text { It is assumed that interaction between linguistic and the semiotic elements effectively enable the scripts to } \\
\text { serve as instruments of inclusion and exclusion, thereby contributing to the production and reproduction } \\
\text { of sociopolitical and cultural equality and inequality. Ultimately, the analysis of the texts will shed light } \\
\text { on the processes of language use formation for indigenous tourism and make the power relations between } \\
\text { the dominant and the dominated transparent. }\end{array}$ \\
\hline
\end{tabular}

